\title{
Vietnam's scientists wait for books and equipment
}

AT THE HeIght of the Vietnam War, US Air Force chief General Curtis Lemay threatened to bomb North Vietnam "back into the Stone Age". Although American bombing never achieved this obective, it nonetheless destroyed a great many buildings, among them - factories, offices, hospitals and research laboratories. Today, in spite of extensive rebuilding office space is generally in very short supply, which means many scientists have to work in cramped conditions, particularly in Hanoi. In Ho Chi Minh City (formerly Saigon), things are not a great deal better, although it did emerge from the war less scarred.

Many of Vietnam's leading scientists have now moved to Ho Chi Minh City, under the auspices of the country's largest research establishment, the Vietnam Scientific Research Centre. Laboratories of experimental biology, petrochemistry, and physics and chemistry of natural products are already established in the city. The latest addition is to be a laboratory of biochemistry and food chemistry, early next year.
One incentive for moving south is the prospect of working in some of the better-equipped food and pharmaceutical industries. The great drawback is a shortage of scientific literature. According to one scientist, such material is in very short supply in Hanoi, but even this constitutes a "wealth much to envy" when compared with the south.

There have been reports of discrimination against scientists who worked for the south during the war. The latest information from $\mathrm{Ho} \mathrm{Chi}$ Minh City however, suggests that northern scientists now in the south are making a major effort to bring their southern colleagues back into the fold. A major obstacle is the lack of available scientific equipment; the accommodation is there, but not the technical support, and it appears there is little the government can do to improve matters at present in the current economic conditions.

- The official British response to Vietnam is somewhat confusing. The Ministry of Overseas Development (ODM) and the Foreign and Com- monwealth Office are known to be concerned with human rights in Vietnam, and new aid programmes are being refused until they are sure that no violations of rights are taking place. But in Vietnam itself, the British Ambassador has bought some $£ 2,000$ of much-needed scientific literature for biologists working at the Vietnam Scientific Research Centre in Hanoi. $\mathrm{He}$ is apparently allocating a further $£ 2,000$ for books next year.

- Back in Britain, neither the Royal Society nor the British Council appears to be doing much to promote contacts with Vietnamese scientists, despite discussions earlier this year about inviting one or more Vietnamese scientists to the UK. A Royal Society official said it was "into China at the moment". But a leading British scientist has urged the Society not to abandon its interest in the scientists of Vietnam who are in urgent need of assistance. The Royal Society, he said, could do much to help, simply by making and maintaining contact with the Vietnamese.

Alastair Hay

\section{India gets ready to tune in to its satellite}

THE building of seven ground receiving stations has begun as the first stage in preparing for the Indian National Satellite (INSAT) programme. The stations will be linked next March with a fractional transponder aboard an INTELSAT satellite above the Indian Ocean.

The INSAT project, costing six crore, is planned to provide remote areas with communications. By the time INSAT-I is launched in 1981, 28 more earth stations will be built all over the country.

INSAT $-I$ is a multipurpose domestic communications satellite with a seven year lifetime to be built by the US Ford Aerospace Corporation. It will provide nation-wide direct television broadcasting to community receivers in rural areas, and continuous meteorological data in the visible and infrared.

Of the 35 ground stations to be built, six will be mobile, four by road and two by air. The one at New Delhi will be the biggest, acting as the control and monitoring station for the others. For meteorological studies about 110 unmanned data collection platforms will be installed at inaccessible spots. INSAT-I will give a cloud picture over the Indian Ocean, the Arabian Sea and Bay of Bengal every half hour.

As well as the Department of Space. other agencies like Posts and Tele- graphs, Indian Meteorogical Department and the Ministry of Information and Broadcasting will be responsible for the establishment and operation of the INSAT network. Most of the equipment needed to build the first seven earth stations will be imported, but Indian-made equipment will be used for subsequent stations. The total INSAT project will cost Rs 175 crore with a recurring expenditure of Rs 11 crores per annum.

\section{Third World seeks low frequency broadcasting}

THE non-aligned countries should seek a suitable frequency for direct sound broadcasting via satellite from the World Administrative Radio Conference (WARC) when it meets next year. This was decided at a three day conference on "Satellite in Broadcasting" among the non-aligned countries recently held in New Delhi.

According to experts at the conference direct sound broadcasting via satellite would enable the membercountries to use relatively inexpensive and mobile receivers. The Indian Information and Broadcasting Minister Shri L. K. Advani said that high costs and the need for high-level expertise need not deter the member-countries from using satellites for communications. Costs could be reduced through collective efforts, he said, and the technical expertise was already available in the developing world.

The purpose of the conference was to prepare a comprehensive report on the technical, economic, legal and political aspects of satellite broadcasting which will be presented at the forthcoming meeting in Tanzania of the Committee for Cooperation among the Broadcasting Organisations of Nonaligned Countries.

The experts felt that the selection of a particular mode of $\mathrm{TV}$ or radio transmission must depend on local conditions. They outlined a way of choosing the best mode taking into account the geography and available infrastructure of the individual country. They also decided to work out a way of exchanging $\mathrm{TV}$ and radio programmes among the member countries currently using the INTELSAT system.

Directly linking the domestic satellist of non-aligned countries is not yet possible because they transmit at high frequencies. The conference therefore agreed to urge the WARC to allot a frequency lower than $54 \mathrm{GHz}$ -the lowest frequency band so far used. India is likely to ask for a long wave frequency because of the work she has done on long wave frequency propagation technology for low cost and long range broadcasts.

Dilip M Salwi 